doi: $10.1016 / 0033-5894(81) 90104-6$

\title{
EMERGENT LITTORAL DEPOSITS IN THE EASTERN CANARY ISLANDS
}

\author{
Meco, J.a , Stearns, C.E. ${ }^{b}$
}

\begin{abstract}
a Beca de Investigación de la Excma. Mancomunidad de Cabildos, Las Palmas Museo Canario, Las Palmas de Gran Canaria, Spain b Department of Geology, Tufts University, Medford, MA 02155, United States
\end{abstract}

\begin{abstract}
K-Ar ages (A. Abdel-Monem, P. D. Watkins, and P. W. Gast, 1971, American Journal of Science 271, 490-521; this paper) and revised paleontological determinations (J. Meco, 1977, "Los Strombus neogenos y cuatenarios del Atlantico euroafricano", Las Palmas, Ediciones del Excmo. Cabildo Insular de Gran Canaria) show that "Quaternary" (R. Crofts, 1967, Quaternaria 9, 247260; G. Lecointre, K. J. Tinkler, and G. Richards, 1967, Academy of Natural Science of Philadelphia Proceedings 119, 325-344) littoral deposits on Lanzarote and Fuerteventura are early Pliocene and late Pleistocene. Early and middle Pleistocene strand lines are not represented. Early Pliocene littoral and marine deposits contain a characteristic fossil assemblage: Strombus coronatus, Nerità emiliana, Gryphaea virleti, Patella cf. intermedia, and Rothpletzia rudista. Differences in elevation record differential post-Pliocene uplift of the coastal platforms on which they lie. Late Pleistocene beach deposits at low elevations belong to two groups, an older with Strombus bubonius and a younger without. Differences in elevation of early Pliocene littoral deposits are reflected by differences in elevation of late Pleistocene beach deposits nearby.
\end{abstract}

